\title{
Analysis of water parameters causing top-dying in mangrove forest trees in the Sundarbans in Bangladesh
}

\author{
Awal, Mohd Abdul \\ Environmental Scientist (Ministry of Environment \& Forest)Founder \& Chief Advisor, Health \& Pollution Research Farm, 23-09-37 \\ Avenue, Apt, No: 1, Long Island City, New York, USA
}

Email address:

abdul_awal2004@yahoo.com

To cite this article:

Awal, Mohd Abdul. Analysis of Water Parameters Causing Top-Dying in Mangrove Forest Trees in the Sundarbans in Bangladesh. Science Discovery. Vol. 2, No. 1, 2014, pp. 1-13. doi: 10.11648/j.sd.20140201.11

\begin{abstract}
Sundarbans is the largest, biologically richest, and most extensive mangrove forest in the world and representing 2.5 percent of the world's natural mangrove forest (Saha, 1991), the Sundarban natural mangrove forest is still the largest natural single tract of mangrove forest and habitats in the world (Christensen, 1984; Seidensticker and Hai, 1983; Hussain and Karim, 1994) with 10, $029 \mathrm{~km}^{2}$ area. The total area of the part of Sundarban in Bangladesh is now about 6,017 $\mathrm{km}^{2}$ (Imam, 1982; Christensen, 1984; Chaffey et al., 1985), which arose due to the eastward shift of the Ganges (Blasco, 1977; Naskar 1999; and Bakshi, 1954; Thom, 1982). Heritiera fomes (Sundri) is the predominant tree species, supporting about $65 \%$ of the total merchantable timber (Chaffey et al., 1985, and Siddiqi, 2001). A unknown and serious-killer disease (top dying) of $H$. fomes in Sundarbans is affecting millions of the trees. An inventory by Chaffey et al., (1985) revealed that there were about 45.2 million top dying trees in the Sundarbans of which 20 million had more than $50 \%$ of their crown affected by top dying. The loss of $H$. fomes will have a major impact on the Sundarbans mangrove ecosystem, which leads to economic losses. Despite various hypotheses as to the causes of this top-dying, the underlying causes are still not well understood. The present work has explored some of the possible factors involved, focussing particularly on the relationship between the amount of top-dying in different places and the concentrations of a number of chemical elements present in the water, in order to test the hypothesis that chemical pollution might be responsible. Other factors such as the $\mathrm{pH}$, salinity and nutrient status were also assessed. Nine plots were selected for sampling of water, and vegetation in order to categorise different areas in terms of their intensity of top-dying. 63 soil samples and 9 water samples were tested, mainly by ICPMS, to investigate certain parameters of the soil and water, such as $\mathrm{Sn}$, Exchangeable $\mathrm{K}$, Soil pH, $\mathrm{Pb}, \mathrm{Zn}, \mathrm{Ni}$, soil pH, $\mathrm{CEC}$, soil nutrients, soil moisture content, and elemental concentrations of 32 other elements. Most of the elements studied had no significant correlation with the top dying of Heritiera fomes. However, the present results have showed that some possible parameters in water in Sundarbans such as Salinity of water, water $\mathrm{pH}$, Water EC, water nutrients could not be directly linked with top-dying of Heritiera fomes (Sundri) in Sundarbans.
\end{abstract}

Keywords: Causal Factors, Water Parameters, Seedling and Sapling Percentage, Trees Diameter, Height, Structure, Species Density, Heritiera Fomes, Mangrove, Sundarbans, Top-Dying

\section{Introduction}

The future of Sundarbans is as directly dependent on the health of her wetlands, as is the future flora and fauna. Considering the limitations of the current planning process in Bangladesh, it is possible that within a few short decades, as water tables fall, rivers run dry and lakes shrivel, water riots will become the order of the day (Awal, 2007). It may also be the case that wars on the subcontinent will more likely be fought over water than oil (Awal, 2007). And until uncontrolled development is restricted, the threat of floods and droughts due to loss of mangrove systems will continue to be present (Sahgal, 1991). Coastal lands include some of the most productive of ecosystems with a wide range of natural functions (Awal, 2014), but are also one of the most threatened habitats because of their vulnerability and attractiveness for 'development' (Awal, 2009). The first global conservation convention, the Ramsar Convention, focused solely on coastal lands and wetlands, and it has recently been strengthened and elaborated with regard to the 
wise use of all coastal areas such as Sundarbans. By the 1970s, the majestic royal Bengal tiger (Panthera tigris) population in the Sundarbans had declined to an alarmingly low level due to forest degradation since tiger habitats are ipso facto high grade forests, and the deer (Axix axis) has also dwindled recently (Ghosh, 1988; Hai and Seidensticker, 1983; Seidensticker, 1986). Water birds serve as another example of decline. With their dependency on patchy food supplies, they must integrate resources over large areas; their nesting and roosting sites vitally require protection (Awal, 2007; Personal observation, 1993-97). Generally, the diversity of species in the Sundarbans was quite high, but the present status regarding population, habitat, and food of wildlife in Sundarbans in Bangladesh is threatened (Awal, 2007; Personal observation, 1993-97). The various environmental factors (such as water parameter) that threaten the Sundarbans are outlined in the following section. At the arrival of British rule in 1765, the Sundarbans forests were double their present size and significant exhaustion of the growing stock led to dwindling by $40 \%-45 \%$ between 1959 and 1983 (Chaffey et al., 1985)

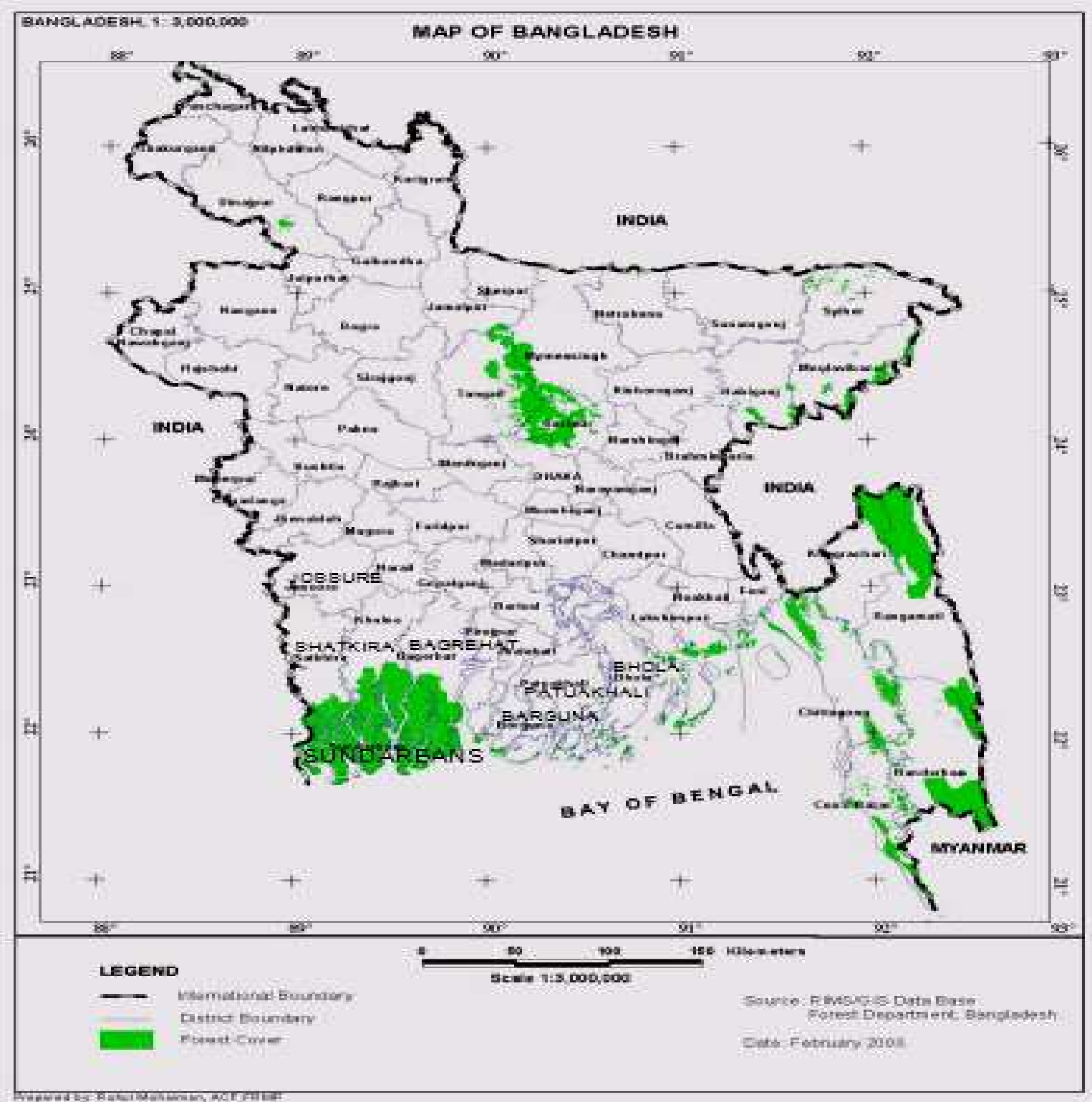

Figure 1.1. Map showing the administrative districts of Bangladesh, including the location of the Sundarbans (the shaded area in the south-west of the country).

(Blasco, 1977; Naskar 1999; and Bakshi, 1954; Thom, 1982, Figure1.1). It occupies a flat deltaic swamp rarely exceeding 0.9 to $2.1 \mathrm{~m}$ above the sea level and most of the area is under water during the high spring tides of the monsoon and the major portion of land is a low plain with maximum $10 \mathrm{~m}$ height above mean sea level (FAO, 1994). 
Sundarbans is subdivided into 8 blocks (Rahman, 2003) and further subdivided into 55 compartments (Figure 1.2), varying in size from 4000-16,000 ha (Tamang, 1993), depending on the height classes \& stocking conditions of the forest trees. The forest lies just south of the topic between $21^{\circ} 38^{\prime}-22^{\circ} 30^{\prime}$ North latitudes and $89^{\circ} 0^{\prime}-90^{\circ} 0$ 'East longitudes. Within the total areas of the Sundarbans,
Heritiera fomes constituted $63.8 \%$ among the total tree vegetation (Chaffey et al., 1985).

\subsection{Location}

The Sundarban mangrove forest is located mainly at the southern portion of the Gangetic delta bordering on the Bay of Bengal of Bangladesh.

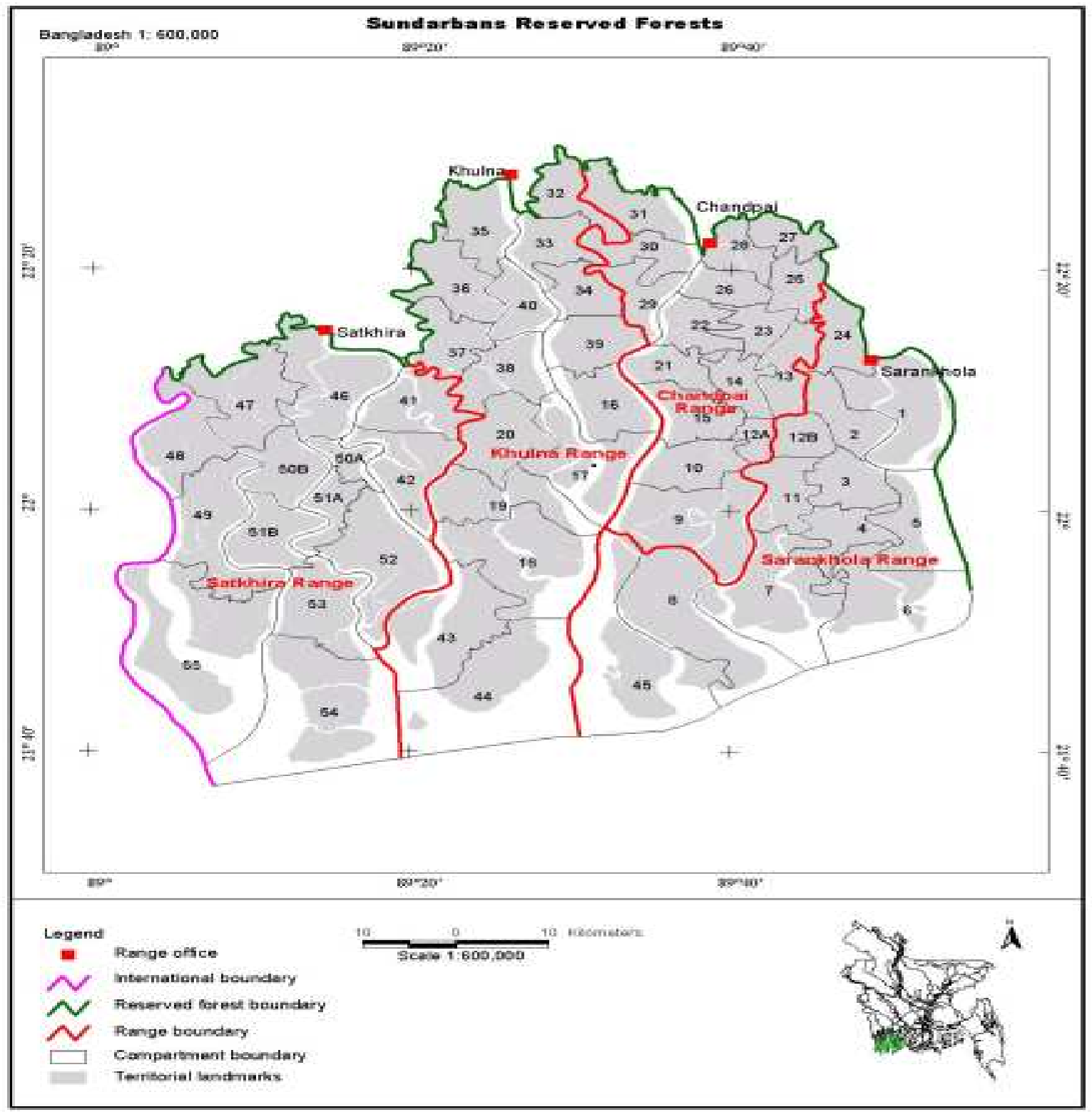

Figure 1.2. Shows compartment numbers and Ranges of Sundarbans Reserved Forest.

\subsection{Climate of Bangladesh Sundarbans}

The climate of Bangladesh is sub-tropical and tropical with temperature ranging from an average daytime low of $15^{\circ} \mathrm{C}$ in the cold season to a high of $35^{\circ} \mathrm{C}$ in the hot season (Statistic of Bangladesh, 2006). Mean annual rainfall varies from about $1,800 \mathrm{~mm}$ at Khulna, north of the Sundarbans, to $2,790 \mathrm{~mm}$ on the coast (Choudhury, 1968). Relative humidity is high $(80 \%)$ in Sundarbans, and annual mean relative humidity in this forest varies from $75 \%-80 \%$. There is a six month dry season during which evapo- transpiration exceeds precipitation. Conditions are most saline in February-April, the depletion of soil moisture being coupled with reduced freshwater flow from upstream (Awal, 2007). Temperatures rise from a daily minimum of $2-4^{\circ} \mathrm{C}$ in winter to a maximum of about $43^{\circ} \mathrm{C}$ in March and may exceed $32^{\circ} \mathrm{C}$ in the monsoon with the average being about $24^{\circ} \mathrm{C}$ in 
January and $35^{\circ} \mathrm{C}$ in June (Awal, 2007; Imam, 1982). Storms are common in May and October- November and may develop into cyclones, usually accompanied by tidal waves of up to $7.5 \mathrm{~m}$ height (Awal, 2007; Alam, 1990; Christensen, 1984; Seidensticker and Hai, 1983).

\subsection{Barrage Construction and Water Flow Changes}

In the complete natural process, land in the Sundarban is formed by the silting up of the interlocking creeks, forming islands that eventually connect and are permanently above the water level and become slightly acidic (Awal, 2007; Own observation, 1993 -1997). As a result, soil fertility has declined, and many rivers have become moribund (Mitra, 1954). The Sundarbans is therefore a dynamic natural resource, which may be affected by changing chemical and physical properties of water and soils which could affect forest growth. In the early 1970s, the Government of India constructed the Farakka barrage $(2,745 \mathrm{~m})$ and put it into full operation in 1975 across the Ganges some $19 \mathrm{~km}$ from the Bangladesh border. Possibly due to this barrage, some new islands have formed, and siltation has begun to accumulate along the shore of the islands as well as sand being blown or washed away (Awal. 2014; Own observation, 1993-97; Seidensticker and Hai, 1983). Apart from Baleswar River the waterways carry little freshwater as they are cut off from the Ganges, the outflow of which has shifted from the Hooghly- Bhagirathi channels in India progressively eastwards since the $17^{\text {th }}$ century (Awal, 2007). They are kept open largely by the diurnal tidal flow (Seidensticker and Hai, 1983). The moisture content of mangrove soils has been reported to vary from $43 \%$ to $196 \%$ by dry weight of the soil by Giglioli and King (1966, 1995), and a similar range of values has been reported for surface soil moisture content of about $28.6 \%$ to $43.3 \%$ by dry weight (Faizuddin, 2003).

\subsection{Hydrology and Tides}

A large part of the Sundarban remains above tidal level during the lean season, while only a part is flooded during the spring high tides and a small part in the South and West is tidally flooded throughout the year. However, the whole of the Sundarbans becomes submerged during high monsoon tides. The depth and duration of tidal inundation depends on factors including: (1) the distance from the sea and the main river; (2) local relief; (3) the general elevation of the area; and (4) the load content of the inundating water. These factors also influence the ecological conditions of a site within the Sundarbans. The Sundarbans are crisscrossed by a network of interconnecting channels (Islam, 2003) and the main rivers are the Baleswar, Passur, Sibsa, Kobadak, Jamuna and Raimangal. The Baleswar and Passur rivers are linked with the Ganges through the GoraiModhumati, and the Arial khan rivers. The Sibsa and Kobadak rivers are not connected with the main flow of the Ganges during the lean season. The Baleswar, washing the eastern fringe of the Sundarbans, receives the bulk of the
Ganges water while the Passur shares only a few cusecs during the lean season (Awal, 2007; Own observation, 1993-97).

\subsection{Salinity}

Numerous authors have discussed the influences of tidal flooding and salinity on the distribution and zonation of mangrove vegetation (Chapman, 1977). There are distinctive plant / animal relationships existing in tidal marshes (Daiber, 1974). Salt-marsh formations in tropical latitudes are usually limited in extent because of competition with mangrove species (Chapman, 1960; Davies, 1940, 1966). In the mud flats and lower salt marshes the soil salinity is closely related to that of the flooding water bodies (Beeftink, 1965, 1966). The growth of salt marshes and siltation may cause profound changes to the structure of mangrove vegetation and its functions and also the accumulating sediments can be converted into dry land and new islands can be enclosed for reclamation (Marker, 1967). A general survey on soil and water salinity was conducted by the Bangladesh Forest Department in 1978, and was aimed at re-delineating the boundary of salinity zones of the Sundarban suggested by Curtis in 1933 . The results indicated that soil salinity increased slightly from east to west and from north to south. Salinity variation showed a seasonal cycle, where soil salinity remained between 2000 and 4500 micro mohs in most parts of the Sundarbans during March to May (Anon, 1972). Karim, 1988; and Bhuiyan, 1994 reported that salinity concentration in the eastern part of the Sundarbans is the lowest and that concentration of salinity in the western part is the highest, but moderate salinity concentration is found in the central part of the Sundarbans. Karim, 1988 recorded and measured salinity of eastern, central and western Sundarbans and has shown that mean salinity from these mentioned zones were $6.29,8.03$, and 12.98 ppi respectively. Bangladesh Forest Research Institute (BFRI), during 1990 to 1994 , conducted mean monthly soil salinity sampling among the compartments 28 (Chandpai), 36 (Kassiabad), and 46 (Burigoalini), and recorded 3168.44, 4590.15, and 6579.79 micro mhos respectively. Mc Millan (1975) observed that the effect of salt on mangroves reduces as the clay content in the soil increases. It is observed that salinity tends to zonal and seasonal variations of soil and water in the Sundarban, and there are prominent but inconsistent variations from year to year and season to season (Chaffey, et al., 1985; Hassan, et al., 1990). For the less brackish zone of the Sundarban (Bogi station areas), the mean soil salinity was recorded as 2 micro mhos/cm, and in the moderate to highly saline zone, the mean soil salinity was recorded as 6 micro mhos/cm (Paul, 2003). Seasonal variation in soil salinity between peak (April to May) and lean (September to October) periods at different locations of the Sundarban remains up to $55 \%$ to $75 \%$. Water salinity at various places of the Sundarbans was found to be 2.5 to 3.5 times higher than that of soil salinity (Paul, 2003). Rainfall and temperature affect salinity trends of the Sundarban. Rainfall 
and sweet water flows from streams and rivers increase washing of excess salt from the forest floor, but dry climatic conditions accelerate evaporation rate and air temperature enhances chemical reactions. In addition, global warming and raising of sea level can affect the mangrove composition (Paul, 2003). After the dry season (March to May), the soil salinity generally remains below 2000 micro mohs in Sundarbans (Awal, 2007). During the rainy season, fresh flows of water increase, and all rivers become full of sweet water. In addition rivers become over flooded due to sudden release of water from the Farakka barrage by India when they get overflow of sweet water, mainly from the Himalaya mountains (Lusai hill is a main source of the Ganges river's fresh water flows within the Himalaya mountains), when they divert this excess water to Bangladesh through opening all barrages including Farakka (Awal, 2007). As a result, almost every year, Bangladesh receives horrible flooding problems, terrible natural and artificial disasters (Awal, 2007). Thousands of people, assets, trees and wild-life, are losing their lives almost every year (Awal, 2007). It is natural to have salts present in any soil and salinity refers not to the presence of salt but rather to the presence of too much salt (Awal, 2007). Some halophyte plants can grow on soils with high salt content e.g. mangrove species particularly Ceriops decandra (Goran tree) in Sundarban (Awal, 2007). The common terrestrial plant systems are composed of "mesophytes", plants adapted to a moderate supply of water (Awal, 2007). In more saline situations, soil salt absorbed by plants may accumulate to toxic levels, leading to the death of cells and tissues; the leaf cell will die, if chloride concentrations reach toxic levels (Na $>0.25-0.50 \%$ and / or chloride above $0.5-1.0 \%$ (Leece, 1984). It has been found that salinity concentration accelerates the rate of catabolism by decreasing the metabolism of Sundri (Islam, 2003), but it has not been established whether this is harmful to the tree. Present result does not support the previous hypothesis foe salinity (Awal, 2007). This result shows salinity has no correlation with the causes of top-dying disease in Sundarbans (Awal, 2007).

\section{Methodology}

In this section the various field and laboratory methods used in this study will be discussed.

\subsection{Field Sampling Methods}

The Sundarbans Reserved Forest is located at the south west corner of the Ganges River Delta close to the Bay of Bengal, mainly on the sea-shore line, river banks, channels, and small creeks. The location of the Sundarbans within Bangladesh has been shown in Figure 1.1.

\subsection{Site Selection and Location of the Study Area}

General reconnaissance of possible sites was made by visiting all the possible regional areas before categorizing and selecting plots for sampling. It was decided to sample from the Chandpai area which is the mostly human accessible and ecologically polluted area. Three compartments from this regional area (range), namely numbers 26, 28 and 31, were selected because they were believed to represent a range of severity of top dying disease, based on relevant maps, documents, literature, consultations with forest professionals, and surrounding peoples. The location of these compartments within the Chandpai area, and the location of this area in the wider Sundarbans is shown in Figure 2.1. Among the three compartments, compartment number 26 was selected as an area highly affected by top-dying, where most of the trees were affected severely. Compartment 26 had pronounced human activities, and also in places is undergoing rapid housing development involving extensive construction activities due to the presence nearby of the Range HQ office in Chandpai. Compartment number 28 was selected as a moderately affected area. This compartment has various human activities including boat making grounds, football-playing grounds, and cattle-grazing fields, all types of major soil erosion, a moderate amount of construction activities and the presence of communities of fishermen. Compartment number 31 was chosen as being relatively little affected by top-dying disease. Of the three chosen compartments, the nearest compartment to Mongla port is compartment 31 , with comparatively modest human activities, but which nonetheless involve clear-cutting of natural vegetation, replanting with other species rather than mangrove or other native species, all types of soil erosion, and construction activities present.

Sampling of soil and water took place within three $20 \mathrm{~m}$ x $20 \mathrm{~m}$ plots, chosen to reflect a range of top dying intensities (High, medium and Low for that area). The sampling was conducted in a randomised block design, in that a plot was sited within a particular top-dying intensity block, but the precise location of that plot was randomised so as not to bias the detailed data collection. Thus in total nine plots were sampled, representing a range of top-dying intensities. Within each of the three compartments, detailed observations of the regeneration and Intensive field data collection was made among these nine selected plots. Observations were performed from observation towers during low and high tides, also traversing the forest floor and vegetation on foot, as well as using a speed boat, trawlers, country-boats, and a launch as required to gain access. All sampling was accompanied by Deputy Rangers, Foresters, and Forest guards armed with a rifle from the local office, Chandpai rang, Bangladesh Forest Department, to prevent a fatal attack by a Bengal tiger (Panthera tigris). Fieldwork was performed in October, 2003 to March, 2004. Locations of sampling points were determined using a Global Positioning System with a precision of 5-10 m. For one typical plot, in compartment 31, the altitude was recorded as $4.4 \mathrm{~m}$ above sea level. 


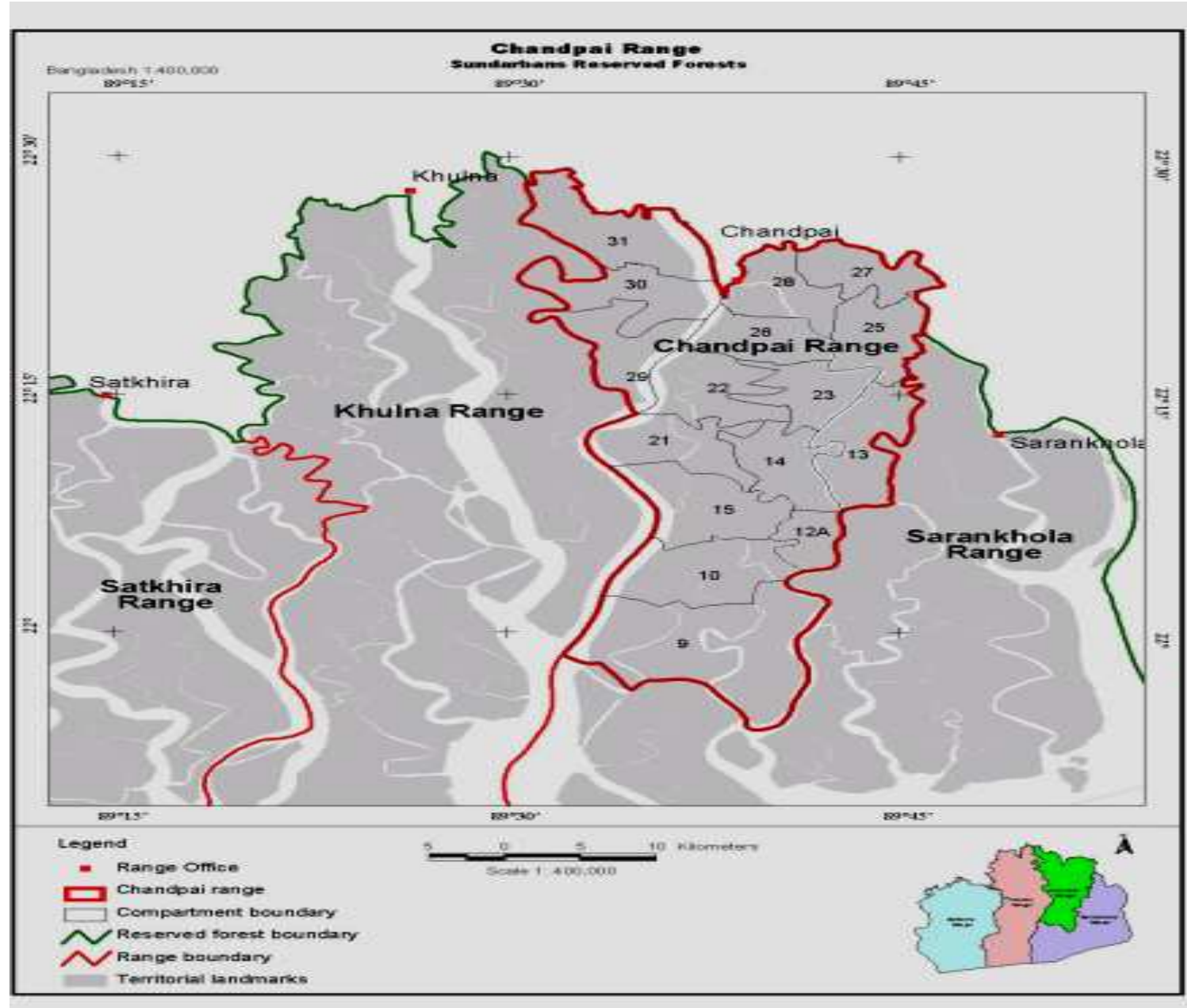

All sampling was accompanied by Deputy Rangers, Foresters, and Forest guards armed with a rifle from the local office, Chandpai rang, Bangladesh Forest Department, to prevent a fatal attack by a Bengal tiger (Panthera tigris).

Figure 2.1. Map showing the location of the numbered compartments within the Chandpai area, and the position of this area relative to other parts of the Sundarbans in Bangladesh (darker shaded area).

Fieldwork was performed in October, 2003 to March, 2004. Locations of sampling points were determined using a Global Positioning System with a precision of 5-10 m (Table 2.1). For one typical plot, in compartment 31, the altitude was recorded as $4.4 \mathrm{~m}$ above sea level.

\subsection{Sampling Methods}

As stated above, from the three selected compartments, a total of nine plots of $20 \mathrm{~m} \times 20 \mathrm{~m}$ were selected. From each of these plots, seven soil samples were collected; one from the centre of the plot, four (one each) from all the corners, and two from the middle sides of the plot. Therefore a total of 63 soil samples were taken. Also nine water samples were collected from nearby rivers, creeks or channels, one from the area of each of the sampled plots. Soil samples were collected from $0-30 \mathrm{~cm}$ soil depth by using a stainless steel spatula and steel cylinder $(d=5.25 \mathrm{~cm})$, and all soil samples were kept in sealed plastic bags. Water samples were collected directly in pre-cleaned plastic-containers. Marking and labelling was performed with a detailed description of the selected sampling site on both the soil- containing plastic bags and water containers, and preserved in portable coolers until arrival at the laboratory at Dhaka University for initial chemical analysis. This field sampling method followed the W.H.O, U.K, and E.P.A systems of standard laboratory and field sampling principles, rules and regulations.

\subsection{Contamination Avoidance Methods}

Cleanness of instruments and glassware in the preparation of soil and water samples for chemical analysis was strictly maintained to avoid all types of contamination during chemical analysis. Instruments were cleaned with appropriate blanks before beginning every experiment. All soil and water samples have been analysed under a clean laboratory environment. Teflon coated beakers, funnels, Advanced Composite Vessel (ACV), plastic caps, volumetric flasks, beakers, pipettes and all other things were first washed by hot tap water, soapy water, cold water, then by deionised water or distilled water and finally with acid leached in deionised water. For drying, all these things were kept for 12 hours in an electrical heating or drying 
oven (Corsair Heating and Catering Ltd; UK). After use, they were washed again by this procedure before storing, to be washed again immediately prior to starting a new analysis.

\subsection{Water EC Determination By EC Meter}

$10 \mathrm{ml}$ of water was placed in a glass beaker, and $50 \mathrm{ml}$ of distilled water was added to the soil. Shaking was done by a mechanical shaker, and stirring was also done 5-7 times to ensure thorough mixing of the mixture. The mixture of soil solution was left overnight for it to reach its stable suspension position phase. Finally the reading of water $\mathrm{EC}$ was recorded by using an $\mathrm{EC}$ meter.

\subsection{Water Ph Determination by Ph Meter}

$20 \mathrm{~g}$ of water was weighed using an analytical balance and placed into a graduated glass beaker. $50 \mathrm{ml}$ of distilled water was added to the soil. Shaking was done, and stirring was also done 5-7 times to ensure through mixing of the mixture. The mixture of soil solution was left overnight for it to reach its stable suspension position phase. The water $\mathrm{pH}$ was then recorded by $\mathrm{pH}$ meter (model; 3305; Jenway Company Ltd). For the water $\mathrm{pH}$, the same amount of water sample and distilled water were taken, stirring was done in the same way as for the soil $\mathrm{pH}$ measurement, and the sample solution left overnight. Filtering was then done using a Whatman No. 42 filter paper. Then the water $\mathrm{pH}$ was recorded using the same $\mathrm{pH}$ meter as above.

\subsection{Particle Size Analysis of Soil By Hydrometer}

Each dried soil sample was ground to a powder using a pestle and mortar, and then sieved through a $2 \mathrm{~mm}$ sieve, 40 $\mathrm{g}$ of air dry fine earth fraction of the sieved soil was then placed into a tall $800 \mathrm{ml}$. graduated glass beaker; and $5 \mathrm{ml}$ of hydrogen peroxide solution $\left(\mathrm{H}_{2} \mathrm{O}_{2}\right)$ was added and the mixture was heated for 10 minutes on a hot plate until the copious frothing cases, and when all frothing was finished, boiling for a few minutes to destroy excess peroxide solution. $100 \mathrm{ml}$ of distilled water was then added to the sample, as well as $100 \mathrm{~g}$ of calgon (sodium-hexametaphosphate) to speed up the chemical reaction, and then transferred contents of the beaker to the mechanical stirrer for 10 minutes. After that it was left overnight in the laboratory for it to reach its stable suspension position phase. Subsequently, the suspension was transferred to the specially graduated cylinder and filled to the lower mark with distilled water with the hydrometer in place, and with a one-litre measuring cylinder fill to the $1000 \mathrm{ml}$. marked without the hydrometer in place. Further shaking was done by a plunger for 1 minute. A blank reading was recorded by hydrometer after 40 seconds. Two hours after taking this first reading, again transferred to the $800 \mathrm{ml}$. beakers and marked at $10 \mathrm{~cm}$. from the base, having stirring for 5 minutes the second reading was taken by hydrometer. During procedures for determination of soil particle size analysis, the temperature was always maintained at $29^{\circ} \mathrm{C}$
(Black, et al., 1965). The particle size analysis was then calculated using the formula. Soil particle size formula $=$ $\left[\left\{\left(\mathrm{H}_{1}-\mathrm{H}_{0}\right) \quad x \quad 20.3\right\} \quad \%\right.$ Weight of dry soil], where hydrometer reading $=\left(\mathrm{H}_{1}\right)$, and blank hydrometer reading $\left(\mathrm{H}_{0}\right)$.

\subsection{Water Content (Moisture Percentage of Soil)}

Approximately $50 \mathrm{~g}$ of soil was sieved by a $2 \mathrm{ml}$ sieve. The sieved material was then weighed and heated to $105^{\circ} \mathrm{C}$ for 24 hours to dry it completely. The dry soil was then reweighed and the difference in weights gave the weight of moisture. This amount of moisture was expressed as a percentage of the original wet soil weight.

\subsection{Statistical Analysis}

Initial statistical analysis of quantitative data, particularly of the elemental concentrations, consisted of calculation of arithmetic means, standard deviations and standard error values for each variable separately. Data on the severity of top-dying for each tree in a plot, which had been recorded as ' not affected', 'mildly affected', 'moderately affected', and 'highly affected', were converted into a four-point scale (0-3), so that they could be summed and an average (median) could be determined for each plot, thus producing an index based on ranked data. Comparisons of the strength of relationship between two variables were assessed by correlation: the Pearson's product-moment correlation coefficient where both variables were fully quantitative or the Spearman's rank correlation coefficient where the top-dying index was one of the variables. In the case of the Spearman's coefficient, the probability of the outcome was determined by using the approximation to a t-statistic appropriate to these tests (Sokal and Rohlf, 1981). Occasionally, a Pearson's correlation coefficient was calculated where top-dying was one of the variables, in order to check on the extent of the difference between the rank and quantitative versions for these data. MINITAB Release 14 Statistical Software has been used for windows on CD-ROM, 2004 edition for all data analysis, both statistical and graphical, except for those produced automatically by the Excel package attached to the ICPMS.

\section{Results}

This section includes the initial chemical analysis of soil and water samples carried out in the Department of Soil, Water, and Environment, at Dhaka University, Bangladesh, together with the further soil analyses and the establishment and execution of instrumental analysis for heavy metals and other components of the soils on the Inductively Coupled Plasma- Mass Spectrometry (ICP-MS) in the Analytical Centre for Cancer Research, and the Department of Geography and Environmental Science laboratories at Bradford University, UK. In the sections that follow, all procedures described were carried out at 
Bradford University except where explicitly stated otherwise. In Dhaka University, the chemical and physical properties of soil and water, including nutrient capacity, were measured by Atomic Absorption Spectrometer (ASS), and Flame Atomic Absorption Spectrophotometer (FAAS). $\mathrm{A} \mathrm{pH}$ Meter was used for measuring both soil and water $\mathrm{pH}$, and an Electro-Conductivity meter (EC Meter) was used for the determination of soil and water caution exchange capacity. Soil moisture content percentage (MC \%) and soil particle analysis were determined by Plunger Hydrometer. Many of the analyses of AAS and FAAS were effectively repeated at Bradford University when elemental concentrations were determined by ICPMS, but not the $\mathrm{pH}$, EC, Soil Moisture or soil particle analyses nor $\mathrm{Na}, \mathrm{K}, \mathrm{Mg}, \mathrm{Ca}, \mathrm{Fe}$ or $\mathrm{Mn}$ concentrations.

\subsection{Severity of Top-Dying in Different Plots and Compartments}

Each individual tree, when it was being recorded, had an estimate made of the severity of top-dying affecting it. In order to be able to calculate an average value per plot, these qualitative assessment categories of severity were assigned a numerical score of 0--3. None of the growth parameters were significantly related to amount of topdying, but the percentage of soil moisture content was; the lower the amount of moisture, the greater the top-dying (Awal, 2007).

\subsection{The Variation in Water Factors between the Different Compartments and Plots in Sundarbans}

The results of the analyses of the basic soil and water parameters such as percentage moisture content, $\mathrm{pH}$ and EC are presented in Table 3.4 below. It is observed from Table 3.12 that the moisture content of soil is quite low with the average of $21.36 \%$ but nowhere exceeding 30.25 . This contrasts with the moisture content thought to be necessary for mangroves of $47 \%$ minimum, usually much higher. For example, the moisture content of mangrove soils has been reported to vary from $43 \%$ to $196 \%$ by dry weight of the soil by Giglioli and King $(1966,1995)$, and a similar range of values has been reported for surface soil moisture content of about $28.6 \%$ to $43.3 \%$ by dry weight (Faizuddin, 2003). The present results are less than half of this (on average), suggesting that this will be adversely affecting the survivorship of the species in Sundarbans. Whether the percentage moisture content value is reflected in the amount of top-dying was tested by a Spearman's rank correlation co-efficient, and found to be significant (Awal, 2014). There was little variation in $\mathrm{pH}$ values neither of soil or water nor, apart from one anomalous result, for CEC of water. However, the CEC values for soil are lower for compartment 28 than for the other compartments.

Table 3.1. General Linear Model for the Soil Nutrients parameters in Sundarbans: Analysis of Variance results, testing for the two factors of Compartment and Plot, together with their interaction. Values given are the F-results together with probability levels. (Significant results are indicated with asterisks). (Key:NS: $p>0.05 * *, p<0.01 ; * * *, p<0.001)$.

\begin{tabular}{|c|c|c|c|}
\hline $\begin{array}{l}\text { Soil Nutrients } \\
\text { Element }\end{array}$ & $\begin{array}{l}\text { Compartment } \\
\text { F }(2,46)\end{array}$ & $\begin{array}{l}\text { Plot } \\
\text { F }(2,46)\end{array}$ & $\begin{array}{l}\text { Interaction } \\
\text { F }(\mathbf{4 , 4 6 )}\end{array}$ \\
\hline $\mathrm{Na}$ (Sodium) & $4.65, \mathrm{p}=0.014 * *$ & $2.14, p=0.13, \mathrm{NS}$ & $1.23, \mathrm{p}=0.31, \mathrm{NS}$ \\
\hline Exc. $\mathrm{Na}$ & $3.47, \mathrm{p}=0.039, * *$ & $0.22, p=0.80$, N.S & $1.08, \mathrm{p}=0.38, \mathrm{~N} . \mathrm{S}$ \\
\hline Soluble-Na & $3.77, \mathrm{p}=0.031 * *$ & $2.20, p=0.12$, N.S. & $0.17, \mathrm{p}=0.95, \mathrm{NS}$ \\
\hline Soil pH & $11.67, \mathrm{p}=0.000 * * *$ & $2.71, \mathrm{p}=0.07 * *$ & $7.46, \mathrm{p}=0.000 * * *$ \\
\hline S (Sulphur) & $4.51, \mathrm{p}=0.016^{* *}$ & $0.32, p=0.73$, N.S. & $1.86, \mathrm{p}=0.13, \mathrm{~N} . \mathrm{S}$ \\
\hline Ca Calcium & $0.37, p=69$, N.S & $2.17, p=0.13$, N.S. & $1.60, \mathrm{p}=0.19, \mathrm{~N} . \mathrm{S}$. \\
\hline (Soluble) K (Potassium) & $1.67, p=0.20$, N.S. & $0.67, p=0.52$, N.S. & $1.64, p=0.18, N . S$. \\
\hline Exc. K (Exchangeable - Potassium) & $5.15, \mathrm{p}=0.01 * *$ & $1.15, p=0.33$, N.S. & $0.80, p=0.53$, N.S. \\
\hline N2 (Nitrogen) & $0.63, p=0.54$, N.S. & $0.70, p=0.50$, N.S. & $1.02, p=0.40$, N.S. \\
\hline $\mathrm{Fe}$ (Iron) & $0.38, \mathrm{p}=0.69, \mathrm{NS}$ & $1.58, \mathrm{p}=0.22, \mathrm{NS}$ & $0.74, \mathrm{p}=0.57, \mathrm{NS}$ \\
\hline
\end{tabular}

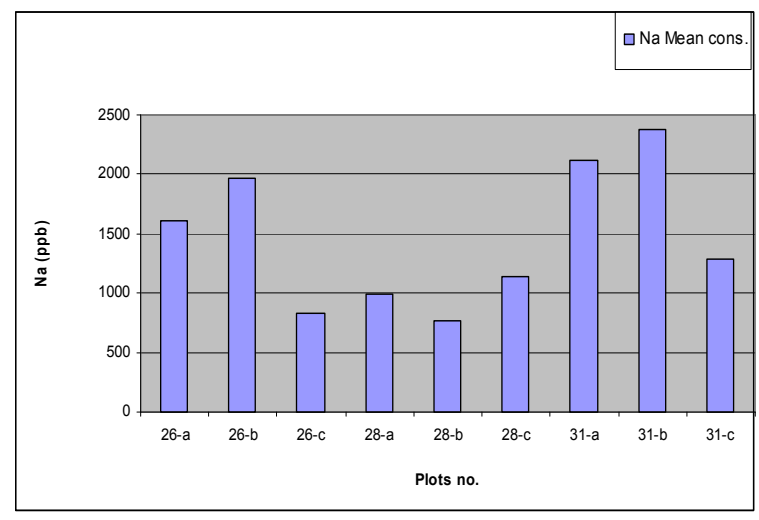

Figure 3.1. Bar chart of the average Na concentrations in the three compartments (26, 28 and 31) sampled in the Sundarbans, with three plots in each compartment.
The results from the analyses of soil parameters (Table 3.4 ; 3.5) show many of the parameters tested to be markedly different in the different compartments but, except for soil $\mathrm{pH}$, not to vary significantly either plot in or the interaction term. Soil $\mathrm{pH}$ was, interestingly, highly or very highly significant with both factors and the interaction.

It is not surprising that there are differences between the three compartments, as they had been selected in order to demonstrate a range of circumstances that might contribute to top-dying, such as nearness to human activity. As an example of the results shown in respect of this factor, Figure 3.1 shows a bar chart of the average $\mathrm{Na}$ values in the three compartments. It indicates that the compartments could be ordered in the sequence of 28,26 , and 31 with 
respect to this parameter, which corresponds with their location and how close they are to the coast line. The fact that there is no significant difference between plots for any parameters (other than $\mathrm{pH}$ ) may be an indication that there is little variation in these parameters over the relatively small distances between plots; or the selection of plots based on top-dying has not selected for variation in these parameters because they are not correlated with the amount of top-dying. It is interesting that there were no significant interactions (apart from soil $\mathrm{pH}$ ). This indicates that the effects evident between compartments can be considered independently of any plot effects-possibly operating at a broader geographical scale. Since soil $\mathrm{pH}$ showed significance in interaction as well as for the two factors separately, to demonstrate how the $\mathrm{pH}$ is varying. In general, it would appear that the higher the $\mathrm{pH}$ value, the higher the amount of top-dying, although there is one result which does not fit with this trend. The pattern of variation between compartments is not consistent for the medium top-dying plots, but is consistent when comparing plots 1 and 3 in each compartment -compartment 31 having the highest $\mathrm{pH}$.

Table 3.2. General Linear Model for the Water parameters in Sundarbans: Analysis of Variance results, testing for the two factors of Compartment and Plot, together with their interaction. Values given are the F-results together with probability levels. (Key: as for Table 3.1).

\begin{tabular}{|c|c|c|}
\hline $\begin{array}{l}\text { Water } \\
\text { Element }\end{array}$ & $\begin{array}{l}\text { Compartment } \\
\text { F }(2,4)\end{array}$ & $\begin{array}{l}\text { Plot } \\
\text { F }(2,4) \\
\end{array}$ \\
\hline Water EC & $0.39, p=0.702$, N. S. & $1.43, p=0.341$, N.S. \\
\hline Water $\mathrm{pH}$ & $0.21, p=0.818$, N.S. & $\begin{array}{l}5.63, p=0.69 \\
\text { Close to Significant }\end{array}$ \\
\hline $\begin{array}{l}\text { Water Mg } \\
\text { Water Magnesium }\end{array}$ & $0.82, p=0.504$, N.S. & $0.83, p=0.499$ \\
\hline $\begin{array}{l}\text { Water S } \\
\text { Water Sulphur }\end{array}$ & $0.82, p=0.504$, N.S. & $0.83, p=0.499$, N.S. \\
\hline $\begin{array}{l}\text { Water, Ca } \\
\text { Water Calcium }\end{array}$ & $1.40, p=0.346$, N.S. & $0.97, p=0.454$, N.S. \\
\hline
\end{tabular}

Table 3.3. Results of correlation between top-dying water parameters in Sundarbans:

\begin{tabular}{|c|c|c|c|}
\hline $\begin{array}{l}\text { Parameters comparing with } \\
\text { Top-dying. }\end{array}$ & $\begin{array}{l}\text { Correlation } \\
\text { (r-value, with7df). }\end{array}$ & $\begin{array}{l}\text { Probability } \\
\text { (p-value) }\end{array}$ & $\begin{array}{l}\text { Sig. or } \\
\text { N.S }\end{array}$ \\
\hline \multirow{2}{*}{$\begin{array}{l}\text { Tree height }(\mathrm{m}) \\
\text { Tallest tree height }(\mathrm{m})\end{array}$} & -0.113 & 0.773 & N.S \\
\hline & 0.072 & 0.854 & N.S \\
\hline Bole diameter $(\mathrm{cm})$ & 0.067 & 0.865 & N.S \\
\hline Tree density $\left(\mathrm{m}^{2}\right)$ & 0.021 & 0.956 & N.S \\
\hline $\begin{array}{l}\text { Soil Moisture Content } \\
\text { Percentage (M.C. \%). }\end{array}$ & -0.736 & 0.024 & $*$ \\
\hline
\end{tabular}

Table 3.4. Results of various parameters of soil and water samples taken from the selected plots. Values are means of soil or water samples.

\begin{tabular}{|c|c|c|c|c|c|c|c|c|}
\hline $\begin{array}{l}\text { Plot } \\
\text { No. }\end{array}$ & $\begin{array}{l}\text { Comp. } \\
\text { No. }\end{array}$ & \% M.C. of soil & $\begin{array}{l}\text { pH } \\
\text { of soil }\end{array}$ & $\begin{array}{l}\text { CEC of } \\
\text { soil }\left(\mathrm{x}^{3} 0^{3}\right)\end{array}$ & $\begin{array}{l}\text { Soil } \\
\operatorname{size}(\mu)\end{array}$ & Particle & $\begin{array}{l}\mathrm{pH} \text { of } \\
\text { water }\end{array}$ & $\begin{array}{l}\text { CEC of } \\
\text { Water } \\
\end{array}$ \\
\hline 1 & 26 & 23.91 & 7.54 & 36.4 & 12.69 & & 7.11 & 19480.0 \\
\hline 2 & 26 & 25.00 & 7.53 & 44.4 & 9.64 & & 6.94 & 17580.0 \\
\hline 3 & 26 & 30.24 & 7.61 & 10.3 & 11.67 & & 7.27 & 18850.0 \\
\hline 1 & 28 & 13.57 & 7.51 & 7.8 & 12.69 & & 7.69 & 17480.0 \\
\hline 2 & 28 & 20.40 & 7.71 & 3.9 & 11.67 & & 7.47 & 18250.0 \\
\hline 3 & 28 & 20.71 & 7.49 & 9.2 & 13.20 & & 7.45 & 19140.0 \\
\hline 1 & 31 & 13.85 & 7.42 & 31.6 & 11.67 & & 7.27 & 17300.0 \\
\hline 2 & 31 & 21.95 & 7.39 & 31.2 & 12.18 & & 7.41 & 17790.0 \\
\hline 3 & 31 & 23.91 & 7.52 & 25.6 & 11.67 & & 7.22 & 17420.0 \\
\hline
\end{tabular}

There were no significant variations in any of the parameters for the water samples, for compartments or for plots, although water $\mathrm{pH}$ was close to significance when comparing between plots (Table 3.2). This presumably implies that the water characteristics were quite consistent between different locations. This is, however, surprising given the significant differences in soil results in Table 3.1; for example, one might have expected water $\mathrm{Na}$ concentrations to vary in similar manner to soil $\mathrm{Na}$ values, since most of the soil $\mathrm{Na}$ has probably derived from that brought in by sea water. It is possible that soil $\mathrm{Na}$ reflects historical differences between compartments that are no longer evident in present day-water, i.e that water characteristics have changed notably in more recent periods. The concentrations of the various heavy metals extracted from the soil samples, when analysed by the two factors ANOVA with replication, gave rise to the results listed in Table 3.1. The majority of elements did not show any significant pattern to the results, for compartment, plot or interaction. However, six elements, Bi, K, P, Sc, Sr and $\mathrm{V}$, did show a significant difference between the three compartments, with compartment 26 having the greatest concentration of each of these elements and compartment 28 had the least. There were also a few other elements 
which showed results close to significance $(\mathrm{P}<0.10)$ which are also worth highlighting for further consideration, namely: $\mathrm{Sb}$ (plots were rather different); $\mathrm{Ca}$ (compartments showing variation); and In (both compartments and interactions were closed to significance). With a large number of statistical tests, it is of course possible for occasional ones to be significant by chance; however, the proportion of tests which were significant or very close to it is higher than would be expected at random, and particularly with $\mathrm{Bi}$ and $\mathrm{V}$ the significance level was high, and therefore it can be started confidently that there are substantive variations in at least some of these chemical elements between different compartments and (with less confidence) some variations between plots.

\subsection{Comparisons of Parameters by Correlation Analysis}

\section{The Relationship between Soil and Water Parameters and Growth of the Trees}

It is desirable to assess whether the chemical characteristics of soil or water have affected the growth of trees. Table 3.4 includes the results of Pearson's correlation analyses where the various parameters are being assessed for relationship with tree height data. Although correlation is not a method of analysis that presumes causality, it might nevertheless be justified in interpreting any significant correlation as evidence that the relevant chemical feature was causing an increase or decrease in tree height at higher values. However, none of the parameters tested showed a significant relationship with tree height, with exchangeable $\mathrm{Na}$ being the only element that even came close $(p<0.10)$. Therefore, it does not appear that tree height is substantially affected by the parameters tested. It should be remembered that illicit felling of trees does occur in the areas studied, and it is possible that this extra factor might be influencing these results by selectively removing the largest trees, and making it more difficult for any correlation to be established. Similar results may be demonstrated when comparing the same parameters with tree diameter (Table 3.2). In this case, however, not only exchangeable $\mathrm{Na}$ but also $\mathrm{Pb}$ gave results close to significance, while exchangeable $\mathrm{K}$ did reach the threshold of significance at the $5 \%$ level. The negative correlation for $\mathrm{K}$ shows that an increase in the amount of $\mathrm{K}$ is associated with a decrease in the girth of the trees. This is an unexpected result, as it might be expected that providing extra nutrients to the trees should lead to them growing better. It is unclear what might be leading to the relationship actually observed.

\subsection{The Relationship between Soil and Water Characteristics and the Amount of Top-Dying}

A primary objective of the present work is to establish whether the concentrations of the various chemical elements, or other soil or water parameters, are having an influence on the amount of top-dying believed to exist in the different plots. To this end, correlations have been determined between the top-dying index and the various parameters. The various heavy metal concentrations, arising from the ICP-MS work, were tested using Spearman's rank correlation coefficient, with the results included in Table 3.3. There were no elements which gave a significant correlation with the index of top-dying, although Sn gave a (negative) correlation which was close to significant $(p<0.1)$. It is clear that, within the scope of the present samples and data collected, there is no indication that heavy metal concentrations are influencing the amount of top-dying, with the possible exception of Sn. The Spearman's correlation was used here because the topdying data are based on an index, and probably not meeting all the assumptions of truly parametric data. However, the elemental concentrations are fully quantitative data, and using this statistic will result in information loss. Therefore, it was decided to test the Sn data, as well as data for a few other heavy metals (those with the strongest correlations in the previous tests), using the Pearson's correlation coefficient instead in order to assess how different the results would be if the data were treated as fully quantitative. The results from these tests, as well as the tests on other soil and water parameters, are shown in Table 3.2. The result for $\mathrm{Sn}$ has changed probability slightly, but sufficiently to become significant, while the result for $\mathrm{Pb}$ has moved to becoming less than $10 \%$ significance. All other results were clearly non-significant. Consequently it may be concluded that there is very little in terms of chemical parameters that shows any clear relationship with the amount of top-dying, with $\mathrm{Sn}$ and possibly $\mathrm{Pb}$ being the only elements with any notable effect. It may also be concluded that, while use of the quantitative Pearson's correlation coefficient slightly increases the significance of the results, it does not substantially change the conclusions that arose from using the rank correlation technique.

Table 3.5. Pearson's correlation coefficient values form assessing the relationship top dying index value and the concentrations of various elements (in ppb). Key to symbols: N.S. = not significant, $p>0.05 ; *=$ $0.05>p>0.01, p<0.1=$ not significant, but close to fit.

\begin{tabular}{|c|c|c|c|}
\hline Name of Elements & $\begin{array}{l}\text { Value of } r \\
\text { (with 7df) }\end{array}$ & $\begin{array}{l}\text { Probability } \\
\text { (P-value) }\end{array}$ & Significance \\
\hline Nickel (Ni) & 0.377 & 0.317 & N.S \\
\hline Lead $(\mathrm{Pb})$ & 0.594 & 0.092 & $\mathrm{p}<0.1$ \\
\hline Soil pH & -0.240 & 0.534 & N.S \\
\hline Water $\mathrm{pH}$ & 0.307 & 0.422 & N.S \\
\hline $\begin{array}{l}\text { Exchangeable } \\
\text { Potassium (Ex. K) }\end{array}$ & -0.022 & 0.956 & $N S$ \\
\hline $\begin{array}{l}\text { Exchangeable Sodium } \\
(\text { Ex. Na) }\end{array}$ & -0.367 & 0.332 & NS \\
\hline $\begin{array}{l}\text { Soluble Sodium } \\
(\mathrm{Na})\end{array}$ & 0.165 & 0.672 & $N S$ \\
\hline $\begin{array}{l}\text { Soil Sulphur } \\
\text { (S) }\end{array}$ & -0.079 & 0.841 & $N S$ \\
\hline $\begin{array}{l}\text { Tin } \\
(\mathrm{Sn})\end{array}$ & -0.705 & 0.034 & $*(\mathrm{P}<0.05)$ \\
\hline $\begin{array}{l}\text { Zinc } \\
(\mathrm{Zn})\end{array}$ & 0.532 & 0.140 & N.S \\
\hline
\end{tabular}


There was also a significant ANOVA when testing the variations in soil $\mathrm{pH}$ across plots and compartments, which was also shown to be the case for top-dying intensity. Comparing figures in the table 3.5 , it would suggest that about two thirds of the elements have concentrations which are elevated compare to other reference sources in the Sundarbans. This would be consistent with the evidence that heavy metals were having an influence on top-dying intensity. The elements $\mathrm{Pb}, \mathrm{Sn}$, and $\mathrm{Zn}$ were highlighted earlier in this discussion, and although not all of them quite reached statistical significance, the positive trend linking two of them to top-dying suggests a likely mechanism of influence, namely that greater concentration of the heavymetal weaken the resistance of the tree to attack by the pathogenic fungi. This might well be a process that other elements contribute to as well, but has not been picked out by the analysis as showing a link because of the variability between samples inherent in the data. In this respect, the anomaly of the negative relationship indicated for $\mathrm{Sn}$ is harder to explain, but a possible process might be an antagonistic response of $\mathrm{Sn}$ and another element, so that when $\mathrm{Sn}$ is less abundant the other element can have a stronger (deleterious) effect on the trees, thus allowing more top-dying to occur. A further point is that variations in soil $\mathrm{pH}$ from site to site (shown to be significant) will also have a marked effect on the bio-availability of some of these heavy metals, and thus perhaps influence top-dying. The present data also contribute evidence regarding other suggested hypotheses for the causes of top-dying. The nonsignificant relationship between soluble or exchangeable $\mathrm{Na}$ and the amount of top-dying, or with the amount of tree growth, strongly suggests that the hypothesis of salinity changes being the cause of top-dying is not correct. However, the data on moisture content percentage do indicate that the Sundarbans has lower values than many other mangrove forests, and the values obtained are rather low even compared to others obtained from the Sundarbans (Faizuddin, 2003). This suggests that the Sundarbans is experiencing problems with its water supply, which may be linked, at least in part, to the construction of the Farraka barrage (FAO report, 1984). If the drainage system of the water basin is poor, the tendency towards more acidic soil and water may increase (Christensen, 1984). The evidence presented in this paper therefore points not to one specific factor as being entirely responsible for the increasing amount of top-dying, but rather to a combination of factors; changing water supply and heavy metal contamination in particular, coupled with possible $\mathrm{pH}$ changes, lead to a weakening of the trees, which are then more susceptible to greater attack by pathogens and lowered resistance to them by the trees. This combination of factors is also supported by the comments of the people interviewed, who suggested many different factors as the cause as well as implying that the change was gradual by not being able to pick out a specific starting date to the problem. This would be precisely the pattern that might be expected where no one factor was solely responsible, and the combinations of factors might be somewhat different in different areas. Of course, having a number of interlinked factors as believed likely causes of the problem makes a solution to the problem more difficult. Some suggestions for ways of alleviating the problems, as well as further research that could be done, are included in the section below.

\section{Conclusion}

Although there were only a few individual chemical elements which showed significant correlations with the amount of top-dying, there was evidence of elevated heavymetal concentrations of many elements in the Sundarbans, which are likely to contribute to the increase in top-dying observed. There were also significant differences between different areas in the Sundarbans, and evidence of water supply problems to the system. Therefore, it is concluded that several factors are responsible for this increase in topdying, rather than one specific factor only.

\section{Acknowledgements}

My research work was supported financially by the Peoples' Republic of Bangladesh and the Asian Development Bank (ADB), whom I thank. Particular thanks are due to the ADB head office, Manila for their support and help. I thank sincerely Dr. W.G.H. Hale (Principal Supervisor), University of Bradford, UK, Professor Mike Ashmore (Technical Supervisor), University of York, UK and Dr. P.J. Hogarth for their advice and comments on the work; Dr. Ben Stern and the staff at the Analytical Centre, Bradford, for their help with the ICPMS analyses; Professor Sirajul Hoque, Mustafa (lab Technician)and staff at Dhaka University for providing facilities; and staff of the Forestry Service, Bangladesh Government, for field assistance. Moreover I indebted to my beloved parents ( Munshi Aowlad Hossain, Mrs. Ashrafunness), my wife (Dr. Shahanaj Khatun), my son (Munshi Tasneem Redowan), my daughter (Marwa Ashra), my beloved brothers (Munshi Abul Kalam Azad), and (Munshi Abdus Salam) and my 6 sisters (Layla Anjumand Banu (Chandu), Akter Rashida Banu (Turi), Saleha Pervin (Lili), Azmeri Ferdowsi (Dolly), Jannatul Ferdowsi (Polly) and my beloved youngest sister Bedowra Ferdowsi (Jolly) as well as all family members for their inspiration and help.

\section{References}

[1] Anonymous, 1972. Ecology. In: Penyata tahunan perhutanan di-Malaysia Barat 1968. Government Printer, Kuala Lumpur.: volume 6.1.

[2] Bangladesh Bureau of Statistics, 2006. Statistical Yearbook of Bangladesh, Statistics Division. Ministry of Planning. Dhaka, Bangladesh. 
[3] Awal, M.A. (2007). Analysis of possible environmental factors causing top-dying in mangrove forest trees in the Sundarbans in Bangladesh. PhD thesis, University of Bradford; p: 1-170.

[4] Awal, M.A., Hale, W.H.G. \& Stern, B. (2009). Trace element concentrations in mangrove sediments in the Sundarbans, Bangladesh. Marine Pollution Bulletin, 58(12), 1944-1948.

[5] Awal, M.A. (2014). Correlation between the chemical composition of the surface sediment and water in the mangrove forest of the Sundarbans, Bangladesh, and the regeneration, growth and dieback of the forest trees and people health. Journal of

[6] Beeftink, W. G. 1965. Dezout vegetative van ZWNederland Beschouwd in Europees verband. (Saltmarsh communities of the SW Netherlands in relation to the European halo-phytic vegetation) Meded. Landbouwhogesch. Wageningen, 65(1): 2-166.

[7] Beeftink, W.G. 1966. Vegetation and habitat of the salt marshes and beach plains in the south-western part of the Netherlands. Wentia, 15: 83-108.

[8] BFRI, 1990-95. Annual Research Report. Silviculture Genetics Division. Bangladesh Forest Research Institute (BFRI), Chittagong, Bangladesh.

[9] Bhuyan, A. A. 1994. Draft final report of the soil scientist. FAO / UNDP Project-Integrated Resource development of the Sundarbans Reserved Forest, Khulna, Bangladesh, 124 pp.

[10] Blasco, F. 1975. Mangroves in India. French Institute of Pondicherry. Trav. 14: 1-80.

[11] Blasco, F. (1977). Outlines of Ecology, Botany and Forestry of the Mangals of the Indian sub-continent. In: Wet coastal ecosystem (ed. V.J. Chapman), Elsevier, Amsterdam 13(1), 19(2).

[12] Chaffey, D. R; Miller, F.R; Sandom, J. H. 1985. A forest inventory of the Sundarbans, Bangladesh, Main report, Project Report No.140, 196 pp; Overseas Development Administration, London, U.K:195-196.

[13] Champion, H.A. 1936. A preliminary survey of the forest types of India \& East Indian, For. Rec. (N.S.), 1: 286.

[14] Chantarasri, S. 1994. Integrated Resource Development of the Sundarban, Fisheries Resources Mangagement for the Sundarban, UNDP / FAO, BGD / 84 / 056, Khulna, Bangladeshp: 170-172.

[15] Chapman, V. J. 1960. Salt Deserts of the World. Hill, London, pp. 391-392.

[16] Chapman, V. J. 1977. Ecosystem of the World, Wet Coastal Ecosystems, Vol-1, Oxford-New York, Elsevier Scientific Publishing Co, 1977: 79-80.

[17] Chaudhury, A.M. 1968. Working Plan of Sundarbans Forest Division for the period from 1960-61 to 1979-80, 82: East Pakistan Government Press, Dacca.

[18] Chowdhury, J. H. and Baksha, M.W. 1983. Studies on the role of Chrysocroa sp. in the initiation of top dying of Sundry. Bano-Biggyan Patrika, 12 (1\&2): 30-34.
[19] Christensen, B. 1984. Integrated development of the Sundarbans, Bangladesh: Ecological aspects of the Sundarbans. Reported prepared for the Government of Bangladesh. FAO report no. FO: TCP/ BGD/2309(MF) W/ R0030.

[20] Curtis, S.J. 1933. Working Plan for the forests of the Sundarbans Division, for the period from $1^{\text {st }}$ April 1931 to $31^{\text {st }}$ March, 1951, Vol.1, 175 p. Bengal government press, Calcutta, India.

[21] Daiber, F.C. 1974. Salt marsh plants and future coastal salt marshes in relation to animals. In: R.J. Reimold and W.H. Queen (Editors), Ecology of Halophytes. Academic Press, New York, N.Y:475-510.

[22] Davis, L.V. and Gray, I.E. 1966. Zonal and Seasonal distribution of insects in North Carolina salt marshes. Ecological Monographs, 30(3) 275-295.

[23] Ellison, J. C. 1998. Impacts of sediment burial on mangroves. Marine Pollution Bulletin 37: 420-426.

[24] Faizuddin, M. 2003. Research on the Top Dying of Sundri in Bangladesh: 43, Mangrove Silviculture Division, Bangladesh Forest Research Institute, Khulna, Bangldesh.

[25] Faizuddin, M. and Islam, S.A. 2003. Generated Technology and Usable Information of the Mangrove Silviculture. Mangrove Silviculture Division, Bangladesh Forest Research Institute, Khulna, p. 17.

[26] FAO, 1994. Review of the state of world marine fisheries resources. FAO Fisheries resources. FAO Fisheries Technical Approach Paper 335:143.

[27] Field, C. 1995. Journey amongst mangrove. International Society for Mangrove Ecosystems, Okinawa, Japan.140 pp.

[28] Ghosh, D.K. 1988. Natural caverns and underground Space for Controlling Environmental Hazards in Central India, "Proceedings of International Symposium. Rock-Stone, Sweden, volume 1, pp. 289-294.

[29] Hassan, M. M. 1984. Soil formation in the recent deltaic region of Bangladesh. Bangladesh Journal of Soil Science $20: 37-45$.

[30] Hassan, M. M. 1988. Soil and Salinity of the Sundarbans in relation to top dying, regeneration and survival of Sundri. UPR of Bangladesh Forest Research Institute, Chittagong:

[31] Hassan, M. M.; Mazumder, A. H.; Islam, A. T. M. N. and Hossain, A.T. M. E. 1990. Soil, hydrology and salinity of Sundarbans in relation to top dying, regeneration and survival of Sundri (Heritiera fomes) trees. In: Rahaman, M. A.; Khandakar, K.; Ahmed, F.U. and Ali, M.O. (Eds.). Proceedings of the Seminar on Top Dying of Sundri (Heritiera fomes) Trees. Bangladesh Agricultural Research Council, Dhaka: 1- 11.

[32] Imam, S. A. 1982. The Sundarbans and its future. In: proceedings of the Second Bangladesh National Conference on Forestry, Dhaka, Bangladesh, p.19-24.

[33] Islam, M.A. 2003. Top Dying of Sundri. Bangladesh Forest Research Institute, Chittagong, Bangladesh, 48pp.

[34] Jimenez, J. A; Cintron, and G. Lugo, A.E. (1985). Tree mortality in mangrove forests. Biotropica 17(3): 177-185. 
[35] Jimenez, C. Y. 1993. Soil compaction as a constraint to tree growth in tropical and subtropical urban habitats. Environmental Conservation. 20: 35-49.

[36] Leece, D. R. 1984. Effects of Salinity and Pesticides on Terrestrial Plant Systems, Pollution and Plants, (Eds.) D.M.H. Cheng and C.D. Field (1984):23-42.

[37] McMillan, C.1975. Interactions of soil texture with salinity tolerances of Avicennia germinans (L.) Lam. And Laguncularia racemosa (L) Gaertn from North America. In: Proceedings of the International Symposium on Biology and Management of Mangroves, (eds.) G.E. Walsha, S.C. Snedaker and H.J. Teas, Volume 2: 561-68.Gainesville, University of Florida, U.S.A.

[38] Ministry of Environment and Forests, and International Union for Conservation of Nature (1991). Towards Sustainable Development. The National Conservation Strategy of Bangladesh, Ministry of Environment and Forest and IUCN, Dhaka, Bangladesh.

[39] Naskar, K. and Mandal, R. 1999. Ecology and Biodiversity of Indian Mangroves, Delhi, India, Volume, I \& II, p.21.

[40] Paul, S.P. et al., 2003. A global perspective on cadmium pollution and toxicity in non-occupationally exposed population, Environment, Volume 28, Issues 8, 2003University of Queensland, Australia.

[41] Rahman, M.A. 2003. Genetic Approach to mitigate the top Dying Problem of Heritiera fomes in the Mangrove Forests, Khulna University, Bangladesh, 87pp.

[42] Rahman, M.A. 2003. Mid-term Report on Top Dying of Sundri (Heritiera fomes) and Its Management in the Sundarbans Biodiversity Conservation Project, Khulna.109pp.

[43] Ramsar-Bureau, 2002. New Guidelines for Management Planning for Ramsar Sites and Other Wetlands. Gland, Switzerland: Ramsar Bureau.

[44] Saha U. K; Rahman, A. F. M; Islam, M. S; and Khan, M. S. 1991. Optimizing fertilizer rate for mustard in calcareous dark grey flood plain soil of Bangladesh, Bangladesh. Journal of Soil Science. 22 (1 \&2):14-33.
[45] Sahgal, B. 1991. Sanctuary; Asia. The Complete Ecology \& Wildlife. Bi-Monthly, Volume, XI. No. 2. 1991.

[46] Seidensticker, J. Hai; A. 1983. The Sundarbans wildlife managemen plan: conservation in the Bangladesh (cited in Chaffey et al., 1985), Bangladesh.

[47] Seidensticker, J. 1986. Large Carnivores and the consequences of habitat insularization, Ecology and conservation of tigers in Indonesia and Bangladesh. In: Cats of the World: Biology, Conservation \& management. (Eds. S. D. Miller \& D.D. Eveutt). Wetidal Wildlife Federation, Washington DC, p. 1-41.

[48] Seidensticker, J. \& Hai, M.A. 1983. The Sundarbans Wildlife Management. Bangladesh coastal zone. International Union for Conservation of Nature. Gland, Switzerland.

[49] Seidensticker, J.; Christie, S. \& Jackson, P.1999. Introducing the tiger. Cambridge University press, London, p.1-3.

[50] Sokal, R.R. and Rohlf, F.J. (1981). Biometry. San Francisco, w.H. Freeman.Tamang, K. M. 1993. Wildlife Management Plan for the Sundarbans Reserved Forest. Integrated Resource Development of the Sundarbans Reserve Forest. UNDP /FAO, BGD/84/056, Khulna, Bangladesh.

[51] Thom, B.G.1982. Mangrove ecology- a geo-morphological perspective. 1982, p.3-17.

[52] Tiner, R. W; J R. (1984). Wetlands of the United States: Current Status and Recent Trends. Newton Corner, Massachusetts: U.S. Fish and Wildlife Service, Habitat Resources.

[53] Troup, R.S. 1921. The Silviculture of Indian TreesVolume 1. Clarendon Press, Oxford: 153-544.

[54] WHO, 1981. Resistance of Disease vectors to pesticides. World Health Organisation, Chronicle, 35, 143.

[55] WFB, 2006. The world fact book-Bangladesh. Population of Bangladesh, Wild Fact Book: 2-3. 